\title{
Introduction
}

Over the last three decades, many states have experienced transition from authoritarian regimes to democracy, and one of the novel features is that states are increasingly expected to address past human rights violations. The number of states addressing past violations has been increasing ever since the wellknown trials and a truth commission in Argentina. ${ }^{1}$ Since then, 37 countries have established truth commissions and countries like Kenya and Mexico are currently considering it as a viable option. ${ }^{2}$ A truth commission is a government body temporarily set up to investigate a past history of human rights violations. ${ }^{3}$ Famous examples are in Argentina, Chile, and South Africa but there are many lesser known cases, such as the National Committee for Investigation of the Truth about the Jeju 4.3 Events (4.3 Committee) in South Korea. ${ }^{4}$

\footnotetext{
${ }^{1}$ Ellen Lutz and Kathryn Sikkink, "The Justice Cascade: The Evolution and Impact of Foreign Human Rights Trials in Latin America," Chicago Journal of International Law 2 , no. 1 (2001).

${ }^{2}$ David Backer, "Cross-National Comparative Analysis," in Assessing the Impact of Transitional Justice: Challenges for Empirical Research, ed. Audrey R. Chapman, Hugo Van der Merwe, and Victoria Baxter (Washington: USIP Press, 2009).

${ }^{3}$ Priscilla B Hayner, Unspeakable Truth: Facing the Challenge of Truth Commission (New York: Routledge, 2002), 14.

${ }^{4}$ An official translation of the 4.3 Committee is the National Committee for Investigation of the Truth about the Jeju 4.3 Incident (http://www.jeju43.go.kr/english/). The use of 'incident (sageon)' is a mistranslation since it reduces the scope and duration of not only the guerrilla warfare and counterinsurgency campaign over seven years but also grave human rights violations. In Korean, sageon literally means an event which causes social problem and attracts social attention and does not have an English connotation of a minor or subordinate event. It is most appropriate to understand sageon as 'an event' in this context and I use "events" to stress that the 4.3 events are complex and multifaceted events with a series of human rights violations. In Korea, major historic events are remembered by their date of occurrence. For example, the Korean War which broke out on 25 June 1950 is referred to as the "6.25 War." Within this tradition, the armed conflicts in Jeju are commonly referred to as the 4.3 events.
} 
The Jeju 4.3 events refer to a series of armed uprisings and counterinsurgency that occurred between 1948 and 1954 in Jeju Island, which is the largest island in the southernmost part of the country. The conflict resulted in an estimated 15,000 to 30,000 deaths, which accounted for 10 percent of the total population of Jeju in $1947 .{ }^{5}$ After fifty long years, the Korean government established its first truth commission in 2000 primarily to collect evidence, publish a report, and establish an archive and second, to identify and honor the civilian victims and their family members. The report, which initially announced 14,028 victims, was published in 2003 and President Roh Moo-Hyun made an official apology in 2004 and participated in a memorial service in $2006 .{ }^{6}$

The efforts to find the truth and restore justice in South Korea have gone largely unnoticed by the rest of the world. However, an in-depth case study of this advocacy process would make three significant contributions to the study of transitional justice. First, despite the fact that the study of truth commissions has noticeably increased, much of the work has been done on the African and Latin American cases. ${ }^{7}$ There are relatively few studies on the Asian experience in

\footnotetext{
${ }^{5}$ Provincial 4.3 Committee, "Report of the Jeju 4.3 Victims," ed. Jeju Provincial Council (Jeju Provincial Council, 1997).

${ }^{6} 4.3$ Committee, Official Report of the National Committee for Investigation of the Truth About the Jeju 4.3 Events (Seoul: 4.3 Committee, 2003), 386.

${ }^{7}$ See David Weissbrodt and Paul W. Fraser, "Report of the Chilean National Commission on Truth and Reconciliation," Human Rights Quarterly 14, no. 4 (1992), Thomas Buergenthal, "The United Nations Truth Commission for El Salvador," Vanderbilt Journal of Transnational Law 27, no. 3 (1994), Audrey. R. Chapman and Patrick Ball, "The Truth of Truth Commissions: Comparative Lessons from Haiti, South Africa, and Guatemala," Human Rights Quarterly 23 (2001), Christian Tomuschat, "Clarification Commission in Guatemala," Human Rights Quarterly 23 (2001), Hayner, Unspeakable Truth: Facing the Challenge of Truth Commission, Joanna. R. Quinn and Mark Freeman, "Lesson Learned: Practical Lessons Gleaned from inside the Truth Commissions of Guatemala
} 
general and very little on the South Korean process in particular. ${ }^{8}$ This, in part, reflects the fact that there are relatively small numbers of truth commissions in Asia but also suggests a lack of awareness and interest in those cases which do not get much attention from the Western media. ${ }^{9}$ Thus, it is important to pay attention to the Asian cases lest our questions, analyses and conclusions be biased due to weighted case selection.

Second, a study of the Korean process leads us to understand one of the important debates in transitional justice literatures on timing - how soon to start a truth commission $?^{10}$ Unlike many prominent commissions created immediately after political transition, it took 13 years after transition and 52 years after the massacres for Koreans to establish their first truth commission. The question of "how soon" is still an unresolved and controversial issue among scholars and practitioners. My study would contribute to this debate by examining the how

and South Africa," Human Rights Quarterly 25 (2003), Joanna. R. Quinn, "Constraints: The Un-Doing of the Uganda Truth Commission," Human Rights Quarterly 26 (2004), Robert I Rotberg and Dennis Thompson, eds., Truth V. Justice: The Morality of Truth Commissions (Princeton: Princeton University Press, 2000).

${ }^{8}$ There are a handful of studies on Sri Lanka and East Timor. See Chandra Lekha Spiram, "Dilemmas of Accountability: Politics, the Military and Commissions of Inquiry During an Ongoing Civil War - the Sri Lankan Case," Civil Wars 5, no. 2 (2002), Carla Bongiorno, "A Culture of Impunity: Applying International Human Rights Law to the United Nations in East Timor," Columbia Human Rights Law Review 33, no. 3 (20012002), Michael J. Matheson, "United Nations Governance of Post-Conflict Societies: East Timor and Kosovo," in Post-Conflict Justice, ed. M. Cherif Bassiouni (Ardsley, NY: Transnational Publishers, 2002). The only English article on the Korean experience is a short piece by Park Won-Soon. See Won-Soon Park, "Bringing Justice to an Unjustified Past in Korea," Human Rights Dialogue 1, no. 8 (1997).

${ }^{9}$ So far, six countries in Asia have established truth commissions: the Philippines (1986), Nepal (1990), Sri Lanka (1994), Indonesia (1999), Korea (2000), and East Timor (2001). Africa and Latin America respectively have had 13 truth commissions.

${ }^{10}$ Hayner, Unspeakable Truth: Facing the Challenge of Truth Commission, 221. 
timing positively and negatively affected the transitional justice process in South Korea.

Third, the Korean experience is unique in terms of the length of operation. The 4.3 Committee started its work in 2000 and is still in operation, screening victims and carrying out various reparation and commemoration projects. The committee has been operating for nine years, and this is exceptional considering the fact that the general tendency in transitional countries is to be in operation between six months to two years. ${ }^{11}$ The 4.3 Committee is, by far, the lengthiest truth commission ever. ${ }^{12} \mathrm{~A}$ close look at the 4.3 Committee is relevant because many recent truth commissions (East Timor, Sierra Leone) tend to operate longer than five years. More and more truth commissions are now created with longer terms and this in part has to do with the South African Truth and Reconciliation Commission, which operated for five years. Since we still have little knowledge about this new trend, this study will help to illuminate the pros and cons of longerterm commissions.

\title{
Jeju 4.3 Events and Human Rights Violations
}

\author{
Jeju 4.3 Events
}

\footnotetext{
${ }^{11} \mathrm{Ibid}$. Brahm, et. al find that 28 out of 36 commissions are in operation less than two years. See Eric Brahm, Geoff Dancy, and Hunjoon Kim, "Truth Commission Database Project: What Is a Truth Commission and How Can We Understand It?" in International Studies Association Annual Meeting (San Francisco, CA: 2008).

${ }^{12}$ Only exception is the Commission of Inquiry into Violation of Human Rights in Uganda. The commission stayed in operation for eight years, though it was suspended for some of this time due to a lack of funding and minimal political support. See Quinn, "Constraints: The Un-Doing of the Uganda Truth Commission."
} 
The major event broke out on 3 April 1948 when the armed uprising against the South Korean Interim Government (SKIG) and the United States occurred under the leadership of the South Korean Communist Party Jeju Committee. ${ }^{13}$ Around 350 leftist guerrillas attacked police stations and killed prominent rightist political figures around the island. ${ }^{14}$ The government initially underestimated the armed uprising and sent only one hundred police reinforcement forces, which was not sufficient to stabilize the situation. Then the government mobilized the members of anticommunist paramilitary groups who were deeply involved in Korean politics using violence in favor of the rightist leaders and the U.S. military government. ${ }^{15}$ But the armed resistance went beyond control and major responsibilities were soon transferred to the military. Civilians were murdered and abused by these groups of perpetrators: police, military, paramilitary groups, and armed guerrillas.

\footnotetext{
${ }^{13}$ The United States set up the military government and officially ruled the southern part of the Korean peninsula until the establishment of the SKIG on 3 June 1947. However, the SKIG was under the effective control of the United States. Scholars generally agree that the United States had a direct military rule over South Korea from 8 September 1945 to 15 August 1948. See Bonnie B.C. Oh, ed., Korea under the American Military Government, 1945 1948 (Westport, Conn.: Praeger, 2002).

${ }^{14}$ In the late 1940s, Korean politics was sharply divided along the line of left-right ideological cleavage. First, the rightists were generally forgiving to traitors and collaborators during the Japanese colonial rule (1910 1945) while the leftists wanted strict punishment. Second, the rightists were pro-American and anti-Soviet, while the leftists, the opposite. Third, the rightists were more reluctant to carry out a revolutionary land reform while the leftists, active and supportive. See Seung-Heum Kil, "The Birth and Development of Party Politics in Korea," in Modern Korean Politics 1945 1948, ed. Research Institute for Korean Politics (Seoul: Seoul National University, 1993).

${ }^{15}$ Bruce Cumings, "American Policy and Korean Liberation," in Without Parallel: The American Korean Relationship since 1945, ed. Frank Baldwin (New York: Pantheon Books, 1974), 85.
} 
Studies of the 4.3 events have been appearing since the democratic transition in $1987 .{ }^{16}$ Most studies have focused on the causes and consequences of the 4.3 events and have led to three major debates. The first is around the characteristics of the armed uprising started on 3 April 1948. Before 1987, the 4.3 events were mostly understood and referred to as "communist rebellions (gongsan pokdong)" in all public records, including government documents, mass media, and textbooks. By defining the key event as a communist rebellion, civilian massacres and human rights abuses were easily justified as collateral to and a necessary part of the efforts to prevent communization. However, scholars and activists have recently begun proposing alternative definitions such as "popular uprising (minjung hangjaeng)" or "democratic movement (minjuhwaunong)."17 These scholars commonly agree that the armed uprising was, first, widely supported by the general public and, second, an inevitable response to the oppression and misrule of the U.S. military government and incompetent Korean government. There are also moderate and more cautious scholars and activists who refer to the "4.3 events (sageon)" or "4.3 (sa-sam)" without expressly defining its characteristics.

\footnotetext{
${ }^{16}$ Ho-Joon Huh, "A Study on the Process of the Jeju 4.3 and Counter-Strategy of the U.S. Military Government" (Jeju National University, 2003), 4.3 Research Institute, ed., $A$ Study on the Jeju 4.3 (Seoul: Yeoksa Bipyeong, 1999), Sung-Hyun Kang, "Sociological Study on the Jeju 4.3 Massacre" (Seoul National University, 2002), Han-Kwon Yang, "A Study on the Jeju 4.3 Rebellion" (Seoul National University, 1988).

${ }^{17}$ Chang-Hoon Ko, "The Process and Characteristic of the 4.3 Uprising," in Study of the Era of Korean Liberation, Vol. 4, ed. Chang Jip Choi (Seoul: Hangilsa, 1989), Myung-Lim Park, "A Study on the Jeju 4.3 Uprising" (Korea University, 1988), Jung-Sim Yang, "A Study on the Jeju 4.3 Uprising" (Sungkyunkwan University, 1995).
} 
There is also debate on the starting date of the 4.3 events. The orthodox view prior to 1987 was that it all started on 3 April 1948 when the communist guerrillas launched an attack. With democratization, however, a revisionist view emerged arguing that it all started on 1 March 1947 when dissatisfaction with the U.S. military government exploded into a demonstration and, the local police, under the control of the U.S. military, opened fire severely injuring six and killing six. This incident led to a general strike in Jeju, followed by a series of confrontations that resulted in the government and local police drastically losing support of the residents. According to this perspective, an armed uprising on 3 April 1948 was one of several instances of public resistance to the U.S. military government which originally started on 1 March 1947.

The debate on the starting date of the process is closely related to a third debate around responsibility for civilian massacres. The traditional argument is that the communist guerrillas were mainly responsible for the disruptions, including the massacres and human rights violations. ${ }^{18}$ In contrast, others recently argue that since the armed protest was merely a response to oppression and misrule, it is the U.S. military government and nascent Korean government that are responsible for the massacres and abuses. ${ }^{19} \mathrm{~A}$ few scholars further

\footnotetext{
${ }^{18}$ Seok-Kyun Jung, "The Truth of Jeju 4.3 Events," Military 41 (2000), Committee on Korean Police History, Korean Police History (Korean National Police, 1972).

${ }^{19} 4.3$ Reporting Team, 4.3 Speaks, 5 vols., vol. 4 (Seoul: Jeonyeweon, 1997), Bruce Cumings, "The Question of American Responsibility for the Suppression of the Chejudo Uprising," in 50th Anniversary Conference of the April 3rd, 1948 Chejudo Rebellion (Tokyo: 1988), Chang-Hoon Ko, "U.S. Government Responsibility in the Jeju April Third Uprising and Grand Massacre - Islanders' Perspective," Study of Regional Government 8, no. 2 (2004).
} 
argue that the United States, not the U.S. military government, is responsible, since the United States had direct rule over South Korea at this time. ${ }^{20}$

\section{Human Rights Violations}

The armed uprisings and the counterinsurgency strategy led to a prolonged confrontation of guerrilla warfare in the rugged and precipitous region of Mountain Halla until 1954. The counterinsurgency strategy was extremely brutal, including mass arrest and detention, forced relocation, torture, indiscriminate killing, and many large-scale massacres of civilians. Most local elites with either rightist or leftist ideological inclination were killed, disappeared, or fled, and this even created a self-mocking saying that "[s]mart ones were all killed during the 4.3 events and only illiterate persons like me survived." ${ }^{21}$ In addition, hundreds of villages were razed when residents were suspected of providing food and shelter to the guerrillas and many villages in the mountains were systematically burned and residents were forcibly relocated to the coast.

The most severe human rights abuses including disappearances and mass killings were concentrated in the earlier period between May 1948 and March 1949. According to the most recent report from the 4.3 Committee, 15,100 victims have been identified, among which 10,729 (71\%) were deceased, 3,920

\footnotetext{
${ }^{20}$ Hae-Gu Jung, "Jeju 4.3 Uprising and the Policies of the U.S. Military Government," in A Study on the Jeju 4.3, ed. 4.3 Research Institute (Seoul: Yeoksa Bipyeong, 1999).

${ }^{21}$ Jong-Min Kim, "50 Years after 4.3," in Study of Jeju 4.3, ed. 4.3 Research Institute (Seoul: Yeoksa Bipyeong, 1999).
} 
(26\%) missing, 207 (1.4\%) injured, and 244 (1.6\%) imprisoned. ${ }^{22}$ The committee also announced 32,403 family members of the victims. If the population of Jeju, which was around 28,000 in 1948 , is considered, the 4.3 events affected almost every family in Jeju. Of all the individual cases, 78 percent were attributed to state agents such as police, military, and paramilitary groups and 12 percent to guerrillas. By this contrast, the report explicitly shows that the tragic consequences resulted from the abuse of state power. Most victims were in their teens and twenties but 12 percent were civilians under 10 years old (5.8\%) or above 60 years old (6.1\%), which is a clear indication of the indiscriminate killing. The report also identified material damages: 300 villages were razed and 20,000 houses were destroyed in the course of the events. ${ }^{23}$

Testimonies and evidence are summarized into four categories in the report: massacre, imprisonment, torture, and suffering related to the guilt-byassociation system. The committee read 14,000 applications from victims and collected 500 additional testimonies from victims, police and military personnel, guerrillas, and scholars. The report confirms systemic civilian massacre in places like Bukchon (300 victims) and Pyoseon (148) and found evidence of indiscriminate and sweeping arrests, illegal detention, and summary executions. Many civilians were arrested and sentenced to death or to life imprisonment in

\footnotetext{
${ }^{22}$ The 4.3 Special Act defines a victim as "anyone who is deceased, missing, or injured due to the 4.3 events." See http://www.jeju43.go.kr/english/index.html

${ }_{23}^{23} 4.3$ Committee, Official Report of the National Committee for Investigation of the Truth About the Jeju 4.3 Events.
} 
makeshift martial courts. Torture was widely used to extract false confession which later was used as justification of summary execution and illegal detention.

One crucial aspect of the report is that it includes suffering related to the guilt-by-association system. This system had long been used to punish grave crimes like treason or rebellion in traditional Korean society. Not only the direct family members of the convicted but also the relatives were inflicted with punishments or disadvantages. It was a convenient tool for cracking down on the independence movement under the oppressive Japanese colonial rule and continued to be used during military regimes. The committee filed many cases where the family members and relatives of victims received unfair treatment in employment, promotion, or travel. Many examples show how past violence can haunt the present and even the future. The report implicitly makes an argument that past abuses of state power, if not properly addressed, can be reproduced and repeated over and over again in different forms of human rights violations.

\section{Transitional Justice Advocacy}

Although studies have been increasing, most of them focus on the 4.3 events themselves and not on the transitional justice process. Only two studies examine the movement process: one is a chapter written by Kim Jong-Min titled " 50 Years after 4.3" and the other is an unpublished manuscript by Kang Duk-Hwan, "Overview of the 4.3 Movement." 24 These are important works that trace the

\footnotetext{
${ }^{24}$ Duk-Hwan Kang, "Overview of the 4.3 Movement," (unpublished), Kim, "50 Years after 4.3."
} 
transitional justice movement in detail from a journalistic viewpoint. ${ }^{25}$ Based on these two studies, I conducted a year-long field research examining archives and interviewing activists, scholars, politicians, and victims and their family members.

As a result of my field research, I divide the advocacy process into four stages based on the main actors and characteristics of the movement. The first stage (1954 1987) was when discourse on and memory of the 4.3 events were totally suppressed by the dictatorial and military regimes. However, a few courageous individuals made sporadic attempts to find the truth, and these pioneers laid the foundation of the movement. The second stage (1987 1992) was when local activists, victims, and journalists first openly advocated transitional justice. The movement focused on finding alternative memories, encouraging the testimony of victims, and challenging public opinion. The third stage (1993-1998) started when the Provincial 4.3 Committee was created under the Jeju Provincial Council in 1993. Since then, the Provincial Committee has taken leadership of the movement and focused on two projects: the first official investigation of the massacres and a mass petition. The final stage (1998 2000) was when victims and activists pursued the passage of the 4.3 Special Act which finally established the 4.3 Committee in 2000 . The main locus of the activism thus moved from Jeju to Seoul, from the periphery to the center of national politics, at the same time also gaining nationwide recognition and support.

\footnotetext{
${ }^{25} \mathrm{Kim}$ Jong-Min was a reporter for local newspaper Jemin-llbo and is currently a senior staff member of the 4.3 Committee. Kang Duk-Hwan was also a reporter is currently a director of the Office of the Victim Registration under the Provincial 4.3 Committee.
} 
From Oblivion to Social Attention (1954 1987)

Although the enormous civilian death toll was unprecedented, the truth had been totally suppressed by consecutive anticommunist regimes. The path toward the establishment of a truth commission was a long and painstaking journey. The Rhee Syng-Man dictatorship, which was responsible for the massacres, lasted six more years until Rhee was ousted out in 1960. Although a short-lived democracy followed, it was soon overthrown by the coup of Park Chung-Hee in 1961. No one publicly uttered a word on the 4.3 events under these dictatorial regimes for over 25 years. ${ }^{26}$ The suppression continued when Chun Doo-Hwan seized power by another coup after the death of Park in 1979. The Chun's authoritarian regime lasted until 1987, when his proclaimed successor Roh TaeWoo agreed to have a direct presidential election.

The most important breakthrough occurred in 1978 when a writer, Hyun Ki-Young, published his short story, Aunt Suni. This was the first attempt to publicly mention the 4.3 events and massacres after two decades of total silence. Almost all activists and scholars agree that this was the key moment in transitional justice history and Kim Jong-Min described Hyun's short story as an incident of a "hole in a dam" in the movements. ${ }^{27}$

The story is a first person narrative in which the main character tells his story as he flies back to Jeju for his grandfather's memorial service. The short story contains two stories - one story of the dead (the narrator's grandfather and

\footnotetext{
${ }^{26}$ Personal interview, Jo-Hoon Yang, Seoul, March 15, 2006.

27 Kim, "50 Years after 4.3."
} 
many other villagers) and the other story of the living (Suni). The story begins with the news that Suni committed suicide in her sweet potato field by poisoning herself. On the same day, the narrator learns that a massacre of 300 villagers, including his grandfather, was perpetrated by the military and police during the 4.3 events. The only survivor of the massacre was Suni. The massacre occurred at her farm and she lost consciousness as the police opened fire, and when she revived, she found out her two daughters were dead. Since that time, Suni lived alone, working at her farm, now and then harvesting the remains of the dead. She lived a miserable life, suffering from nervous prostration and hallucinations and finally committed suicide. The narrator ends his story saying, "Aunt Suni's death is not a recent one but a thirty-year-old death. Although she lived on after the massacre, Suni was killed in her sweet potato field with her two daughters thirty years ago." 28

Aunt Suni not only got attention from the locals but also from readers and critics nationwide. Hyun himself was surprised by the unexpected attention and admitted that he was afraid of the popularity that Aunt Suni was gaining. ${ }^{29}$ Hyun was soon arrested and tortured by government agents and Aunt Suni was banned from publication. Nevertheless, Aunt Suni had a significant impact in underground student movement circles and among social activists. The time between 1978 and 1987 was a period of preparation. Underground activists and scholars slowly and secretly rediscovered the lost memories and repressed

\footnotetext{
${ }^{28}$ Ki-Young Hyun, Aunt Suni (Seoul: Changbi, 1979).

${ }^{29}$ Ki-Young Hyun, "The Motive of My Novel: 4.3 Uprising," Critical Review of Korean History, 20, no. Spring (1993).
} 
discourses of the 4.3 events and massacres. Although there were no manifest actions and tangible achievements, this nine year period was a time of a silent change. Secret and private memorial services were held and a small number of concerned people started to gather together to study, discuss, and remember the 4.3 events. These few became the igniters of the movement, creating various organizations and fully devoting themselves to the movement.

The first breakthrough from absolute silence took place in the realm of cultural expression where the state control and surveillance was relatively weaker than in the political and social realms. Poems, novels, and traditional plays were crucial in evoking long-forgotten or suppressed memories and encouraging intimidated and hesitant victims to tell their stories. ${ }^{30}$ This was a key element of the movement, since the truth had been systematically suppressed for such a long time. The impact of cultural expression was not manifest but "gradually accumulated over time."31

Initial Local Mass Movement (1987 1992) With democratization, a mass and public movement started at the local level. The power and resources that had been accumulating underground after Aunt Suni now came upto the surface. Actors gathered around three major activities memorial services, media coverage, and research. First, students and social movement groups organized the first public memorial service in 1989. A

\footnotetext{
${ }^{30}$ Personal interview, Seung-Kook Oh, Jeju, April 7, 2006.

${ }^{31}$ Personal interview, Kyung-Hoon Kim, Jeju, April 5, 2006.
} 
memorial service was not simply a one day ceremonial event but had a lasting and significant impact on both activists and the public. On the one hand, it provided an arena where activists could discuss the 4.3 events and share information, expertise, and strategies. This network of individuals and groups became a crucial asset of the advocacy that took place over next ten years. This in turn made possible the formation of two solidarity organizations in Seoul and Jeju in 1999 that maximized the effectiveness of the movement. On the other hand, memorial services were always accompanied by a month-long cultural festival that included local artists and cultural activists. Festivals consisted of picture and art exhibitions, traditional plays, testimony hearings, films, concerts, and traditional exorcism. ${ }^{32}$ All these activities contributed to making the 4.3 events and massacres known to the general public.

Second, local newspapers played a key role in discovering and spreading the testimonies and evidence of the massacres. The Jemin-Ilbo published the special report on the massacres over nine years by interviewing 3,000 witnesses. This special coverage was remarkably effective in convincing victims who were still afraid of state violence and social stigmatization to tell their stories. The special reports and victim's testimonies had an escalating effect. As the series continued, witnesses willing to share their stories increased and their testimonies

\footnotetext{
${ }^{32}$ The ritual of exorcism (gut) is a shamanistic way to cure illness by exorcising evil spirits. This exorcism was also used to appease spirits by inviting them, communicating with them, and guiding them to heaven. Local cultural activists believed that it is necessary to appease the souls of the dead and also bridge the dead with the living. Young-Bum Kim, ed., A Struggle for Memory and the Development of Cultural Movement (Seoul: Yeoksa Bipyeong, 2004).
} 
became more accurate and comprehensive. In turn, as witnesses and testimonies increased, media coverage also became more frequent and reliable. ${ }^{33}$

Finally, research was an indispensable factor in the movement, since a half century had passed since the massacres and past governments had intentionally destroyed evidence. Research activities in general and the 4.3 Research Institute specifically played an essential role. The Research Institute was created in 1989 to find evidence of the massacres and disseminate information. It was created by underground scholars and activists in the early 1980s and most of them worked in schools, the public sector, or private firms and volunteered for the Research Institute devoting their entire weekends. Besides its main research activities, the Research Institute played an active leadership role among many movement organizations.

All these efforts reached a climax with the excavation of the Darangshi cave and discovery of the skeletal remains of 11 corpses in 1992 . The cave was discovered by the members of the 4.3 Research Institute who were on a trip to interview victims. The police hurriedly announced that the dead were all guerrillas and the cave was a secret hiding place. However, the Jemin-Ilbo discovered that 19 civilians who took the refuge in the cave were killed by the military and police. The police and military had set a fire with dried grass in front of the cave and closed the exits, suffocating everyone inside. The dead included three who were under 10 years old, three who were over 50 , four women, and nine young men.

\footnotetext{
${ }^{33}$ Personal interview, Jong-Min Kim, Seoul, March 25, 2006.
} 
The remains of the dead along with those of children, women and seniors provided sufficient evidence of indiscriminate killing by the state. It was the first time evidence of the massacre was vividly presented to the general public.

The excavation and national coverage of the Darangshi cave was certainly the most significant event since Hyun's short story. Kim Dong-Man, the former secretary general of the 4.3 Research Institute, stated that the Darangshi cave brought transitional justice advocacy to "another level." ${ }^{34}$ First, it changed the advocacy from that of activists and victims to a public movement by revealing evidence of real, brutal and gruesome state violence. Second, it not only affected the general public but also deeply influenced activist themselves by strengthening their belief and commitment and empowering their voices in Jeju society. ${ }^{35}$ In sum, it actually had a more significant impact on the movement than "one hundred publications or one hundred rallies."36

The Struggle of the Periphery (1993 1997) Although elected as the first civilian President in 1993, Kim Young-Sam gained power by a merge of his party with the old ruling party under authoritarian regimes. Although a few attempts were made to push the issue into national politics, most attempts during this period were frustrated by a lack of will in leaders at the center. However, the Kim Young-Sam administration made an

\footnotetext{
${ }^{34}$ Dong-Man Kim, "The Darangshi Cave Should Be Recovered," Jeju Writers 8 (2002).

${ }^{35}$ Personal interview, Chang-Hoon Ko, Jeju, March 24, 2006.

${ }^{36}$ This was a remark made by the former chief of Jeju police while he was dissuading activists and victims from organizing a public rally immediately after the incident. ChangHoon Ko, "A Story of Discovering the Darangshi Cave," (unpublished).
} 
important advancement in democracy by decentralizing state power and instituting the local government and council system. With the revival of this selfgoverning system, elected council members brought forward the 4.3 events as the first issue at the first meeting. Council members who had their constituency in each county and city were more attentive to the demand for truth and justice which was at its peak due to the discovery of the Darangshi cave. The Provincial 4.3 Committee was created within this political context under the Jeju Provincial Council.

The first step of the Provincial Committee's action plan was to investigate the truth. The Office of 4.3 Victims Registration was created under the Provincial Committee to collect applications from victims, and 17 investigators were appointed to conduct interviews and document evidence. Based on a year-long investigation, the Provincial Committee published the final report in 1995 and announced a list of 14,504 victims. This investigation, which ended in a 585 page report, was a landmark in four aspects. First, an official investigation of the massacres was conducted by a branch of government for the first time. Second, the investigation was complete and thorough. Third, the investigation provided an exact number of victims based on an empirical methodology. It was no longer approximately 15,000 or 30,000 but "at least 14,504 ." Finally, it provided the first analysis of the abuses by presenting the composition of perpetrators. The percentage was similar to the investigation of the 4.3 Committee: 84 percent were killed by state agents and 11 percent by the guerrillas. Therefore, it was this local investigation that first revealed the fact that the massacres and abuses 
during the 4.3 events were mainly committed by state agents, not by the guerrillas.

This report later became a stepping stone in creating the first national truth commission in Korea. It first helped the transitional justice movement by providing official and reliable evidence of state violence and civilian sacrifice. In the course of the later advocacy, activists and victims encountered many people who argued that only a small number of civilians were killed during the 4.3 events, and mostly by the communists. The report was manifest counterevidence to this kind of argument and it was distributed to any individuals or organizations making this argument. ${ }^{37}$ Second, it helped the activities of the 4.3 Committee in a practical way by laying down the groundwork for the national investigation. ${ }^{38}$ One year-long investigation and continued revisions over four years clearly illustrated that the investigation by a national committee would not be an easy process.

However, the investigation was the first step among many action plans. Since the Provincial Committee initially set the goal as "first, to find the truth, and then urge the national government to act," the council members knew that their activities at the local level should not be the final stop. ${ }^{39}$ The first attempt to bring the issue into national politics was made in the form of a petition. The movement took the form of submitting a signed petition by the victims and general public to the National Assembly entreating lawmakers to include the 4.3 events in the

${ }^{37}$ Personal interview, Duk-Hwan Kang, Jeju, March 21, 2006.

${ }^{38} 4.3$ Committee, Official Report of the National Committee for Investigation of the Truth About the Jeju 4.3 Events, 383-85.

${ }^{39}$ The Office of the Secretariat of the Jeju Provincial Council, "A Minute of the 82nd Extraordinary Session (No.2)," (1993). 
agenda. However, after three years of procrastination and lip service, the petition was finally dismissed with an excuse of lack of time. With this huge disappointment, activists and victims realized that they needed a new and more effective approach.

The Enactment Movement (1998 2000)

In 1998, President Kim Dae-Jung, whose political constituency was based in Jeju and who had pledged several times to investigate the truth, was inaugurated. Activists and victims truly believed that a settlement of any sort could come into being only during his tenure. ${ }^{40}$ In order to maximize the effectiveness of the movement, activists, victims, and politicians decided to concentrate their activities and energy into two solidarity organizations which would incorporate all individuals and organizations working on this issue. The Pan National Committee for the Jeju 4.3 Events (Pan National Committee) was created in Seoul and Provincial Solidarity for the Jeju 4.3 (Provincial Solidarity) was set up in Jeju.

From the onset, the situation looked highly promising. A special committee was set up within the ruling party - the National Congress for New Politics - and public hearings and conferences were held to discuss the 4.3 events. However, even after a year, these were the only efforts made by the ruling party and it fell short of what people in Jeju expected. Activists and victims realized that the resolute political will of President Kim Dae-Jung alone cannot lead to success in transitional justice. By early 1999, activists started to focus on

\footnotetext{
${ }^{40}$ Personal interview, Dong-Yoon Yang, Jeju, March 22, 2006.
} 
enacting a binding special law that would guarantee the establishment of a truth commission.

The local council members along with 90 victims and activists carried out a national campaign and made several visits to the National Assembly. Upon their visits, floor leaders of both the ruling and opposition party verbally committed to enact a special law by the end of the year. In each visit, council members and activists stressed that the investigation of the massacres was a pledge that President Kim Dae-Jung had made over ten times. In addition, they reminded politicians that there was no noticeable policy or action so far other than establishing a small committee within the ruling party. The words, "President's pledge" or "will of the President" had been frequently used to push politicians, and many recalled that this - holding politicians accountable for their commitments - was the most effective strategy. ${ }^{41}$

In addition, activists organized weekly rallies, which were effective tools to "push politicians forward whenever there was a delay or deadlock." ${ }^{42}$ Thus, activism existed at two levels: on the one hand, activists and local politicians lobbied national elites and lawmakers for the enactment of the special law and, on the other hand, grassroots organizations made the 4.3 events and massacres known to the local and national public and tried to gain support from outside sympathizers. Two levels of activism closely interacted with and reinforced each other. For example, there were several occasions when activists in Seoul

\footnotetext{
${ }^{41}$ Personal interview, Young-Hoon Kim, Jeju, April 7, 2006, Personal interview, Yang, 42 Personal interview, Yang,
} 
encountered an impasse, since politicians in Seoul would not or could not move forward because of the pressure from former high-level police and military officers. In those cases, activists in Seoul asked leaders of local organizations to organize a political rally in Seoul to press the movement by showing the force of public opinion behind the advocacy. ${ }^{43}$

Despite the verbal promise of floor leaders, there were no tangible advancements. Leaders were hesitant to move forward, claiming that more prudence was needed in addressing an ideologically controversial issue such as the 4.3 events. One congresswoman from the ruling party - Choo Mi-Ae - played a significant role in bringing the 4.3 events into national politics and urging the ruling party to fulfill its commitment. Choo released an official document containing a 200-page list of 1,650 persons who were court-martialed during the 4.3 events. The document was initially discovered by researchers from the 4.3 Research Institute. ${ }^{44}$ However, activists strategically handed the list over to Choo because they believed that it would be much more effective for a newly-elected young congresswoman who was at the center of public attention to announce the list. ${ }^{45}$ It contained detailed personal information along with 5 20 page description of military trials. ${ }^{46}$ Previously, evidence of the massacres exclusively relied upon testimonies of victims and old news reports. This was the first time any document of the government had been discovered.

\footnotetext{
${ }^{43}$ Personal interview, Yang,

${ }^{44}$ Personal interview, Chan-Sik Park, Jeju, April 6, 2006.

45 Personal interview, Ibid.

${ }^{46}$ Chan-Sik Park, "A Massacre of Court-Martialed Persons Related to the 4.3 Events," 4.3 and History 1 (2001).
} 
The release of the document was important in three ways. First, it provided undeniable evidence of the execution of a large number of people in a short period of time without due process. The document provided evidence that most detainees were executed within a month after initial trials and showed that, at some point, 132 prisoners were executed in one day. Since the document was created by state officials, it was indisputable evidence of mass killing in the name of the law. Second, the list was meaningful to the bereaved families who wanted to know whether their family members were killed or missing. The list provided personal information and the place where they were executed. With the release of the list, many families finally decided to have a funeral or build a tomb for the deceased. Some even visited the old or current prison sites with a bit of hope to find the remains of the dead. Third, the timing of the release was crucial in the enactment of a special act since many rightwing and conservative lawmakers at this point objected to the enactment based on insufficient evidence.

In previous regimes, rightwing and conservative lawmakers objected to any political and legal measures for transitional justice because it was clear to them that the 4.3 events were "communist rebellions." However, since President Kim Dae-Jung's inauguration, not many rightwing lawmakers relied on this logic any more. In discussions of the 4.3 events, words representing this viewpoint "reds", "communists", or "rebels" - were now seldom used. The basis of objection now veered toward "insufficient evidence" and "a historic event that cannot be tailored with the current political perspective." Nevertheless, timely release of the 
document silenced all these arguments and made it possible for the concerned lawmakers to proceed without much resistance.

\section{The Establishment of the 4.3 Committee}

Since the release of the document, the process in the National Assembly noticeably accelerated. The first move ironically came from members of the opposition party - Grand National Party. Three congressmen from Jeju proposed the draft of a bill in October 1999. The limitation, however, was that it was the action not of the opposition party but of three individual congressmen. Many activists and victims expressed their concern for the bill since it lacked any party platform or concrete action plan. Some even criticized that the bill was merely a calculated political move aimed at the upcoming election. Nevertheless, the bill was meaningful because it was the first detailed bill to address the 4.3 events by proposing the establishment of a special investigatory body. Moreover, it later became the bill of the opposition party with only a minor change.

The bill included the establishment of an independent committee under the Office of the Prime Minister. Also, it was the first time the 4.3 events were redefined in the political realm as an event other than a "communist rebellion." The 4.3 events were defined using a cautiously chosen neutral term as "a disturbance that occurred from 3 April 1948 in Jeju Island and the subsequent processes of governmental suppression." By using "disturbance (soyo)," authors of the bill tried to avoid mentioning responsible parties of the atrocity. Although lawmakers argued that their definition was neutral without any ideological 
inclination, it was at the center of debate since activists and victims strongly disagreed with this definition. The basic skeleton of a special act started from this bill, including the structure of an investigatory committee, publication of the report, institution of the local executive committee, building a memorial site, and providing financial and medical support for the victims. This bill provided a basic frame of reference since all later bills originated from this bill, and arguments were made for and against this bill. Thus, it was a timely and important bill in the trajectory of the establishment of the 4.3 Committee.

Within a month, activists and victims came up with their version of the bill, which later became the bill of the ruling party. The most important difference was its definition of the 4.3 events, which was "events which occurred in Jeju Island from 1 March 1947 to 27 July 1953 when civilians were abused without good cause during the armed conflicts and governmental suppression by the police, military, and paramilitary groups of the U.S. military government and Korean government." This definition mainly reflected revisionist view of the 4.3 events and differed from that of the opposition party in its characteristic, periodization, and the responsible party of the massacres. Victims and activists wanted to go beyond the definition of a "disturbance" and redefine the 4.3 events as acts of grave human rights violations by the state.

Another difference concerned monetary support including financial and medical assistance to the victims. As mentioned, an article on a financial and medical subsidy was included in the bill of the opposition party. Nevertheless, the word "reparation (baesang)" did not appear and the term "subsidy (bojo)" was 
used instead. The opposition party refrained from using the word "reparation" because the term itself implied that the state was responsible for the massacres and abuses. For conservative lawmakers who strongly believed that the 4.3 events started as a communist rebellion, it was extremely difficult to admit that the state was mainly responsible for the massacres and abuses. In contrast, the bill of victims and activists clearly defined the responsible actor as the state and articulated that the state should make reparations to victims and families.

Two different bills had to go through the negotiation process and these two points - definition and reparation - were at the center of debate. For the ruling party and activists, the definition of the events was the single most important aspect which could never be compromised. It was achieved through fifty long years of research, activism, and investigation. Activists and victims have fought for over fifty years to clear themselves from being characterized as "reds." In addition, most victims were also victims of the guilt-by-association system. The only way to redress the issue was to redefine the 4.3 events as, at least, human rights violations and state violence and, at most, a popular uprising or democratic movement. On the other hand, the opposition party refused any transitional justice measures beyond the investigation and constantly avoided any possibility of including the clause on reparations. Thus, activists and victims held fast to definitions and the opposition party held fast to the principle of no reparations, and this provided a window of opportunity for the negotiation.

For victims and activists, reparations were a secondary matter compared to the investigation of the massacres and redefinition of the 4.3 events so that the 
honor of victims and their family members could be restored by clearing them from being "reds." In addition, activists believed that it was possible to achieve reparations later through activism after the official investigation was completed. Based on their experience with the investigation of the Provincial Committee, activists and victims strongly believed that the truth of state violence would be revealed again in the course of the national investigation, which would provide the grounds to push further for reparations or other transitional justice measures. For activists and victims, the compromise was "a strategic and provisional concession in order to enact a special law." 47

A bipartisan bill was a compromise between the ruling and the opposition party. First, the definition of the 4.3 events was the same as the one proposed by activists and the ruling party. Second, an article on a financial and medical subsidy, not reparation, for the victims was included. The only transitional justice measures that were further guaranteed by the law beyond the establishment of a truth commission were commemoration projects including building a memorial cemetery, museum, and memorial park. Although victims and activists retreated on the reparation issue, the most important ground - the definition of the 4.3 events - was successfully laid down. On 16 December 1999, the bipartisan bill was finally passed even without a vote by virtue of the chairman's authority.

The 4.3 Special Act established three central institutions - the 4.3 Committee, 4.3 Working Committee, and Task Force for the Report. First, the 4.3

\footnotetext{
${ }^{47}$ Ko Hee-Bum, the leader of the Pan National Committee, mentioned "strategic concession (choice)" during a conference held by the 4.3 Research Institute in 2006. It was also confirmed by many leaders including Yang Dong-Yoon and Oh Young-Hoon.
} 
Committee is the highest deliberative organization and was designed to "(1) investigate and reveal the truth, (2) screen and identify victims, and (3) deliberate and make decisions on matters related to restoration of the honor of the victims." The Prime Minister was the commissioner and the members of the committee included the governor of Jeju, victims, and others with the recommendation of the President. Second, the 4.3 Working Committee was instituted under the governor of Jeju and designed to carry out practical businesses entrusted by the 4.3 Committee, such as (1) accepting applications from victims, (2) conducting an initial screening process of victims, (3) administering a financial and medical subsidy to victims. Third, the Task Force for the Report was in charge of collecting and analyzing domestic and foreign evidence to investigate the 4.3 events and publish a report. Nevertheless, it took another nine months to launch the 4.3 Committee and 13 months to constitute and start the Task Force for the Report. These delays indicate that the establishment of the 4.3 Committee in specific and transitional justice process in general were neither smooth nor without obstacles after the enactment of the special law.

\section{Conclusion}

Four lessons can be drawn from the examination of the first truth commission in Korea. First, strong and persistent activism was the single most important basis of the transitional justice movement. Various actors played an important role in different phases but local social justice and human rights activists, students and scholars, and journalists were the pillars of the advocacy. These people were 
mainly motivated by the sense of justice, pursuit of the truth, compassion and empathy, and historical consciousness. One interesting aspect is that victims were not the most active groups in the process. It was rather others who initially tried hard to encourage victims to tell their stories and induce their participation. In part, it had to do with the fact that victims had been closely associated with a very strong taboo - communism - under consecutive anticommunist regimes. Victims were not only abused by brute state violence but also had to go through implicit social discrimination. The family members also suffered from a guilt-byassociation system which left victims in constant fear of the government. The role of activists was extremely important because victims were much more intimidated by state violence than the general public.

Second, the development of democracy and its consolidation was an important precondition for the 4.3 movement. The movement gradually achieved the purported goal as democracy consolidated in Korea. As stated in the report, transitional justice advocacy has been developed "in conjunction with the advancement of democracy." ${ }^{48}$ A key breakthrough occurred in 1993 when the self-governing system, which marked the localization of state power, was instituted. The creation of the highly important Provincial 4.3 Committee was possible within this political context. The Provincial Committee was a stepping stone for the national truth commission. Moreover, the very existence of the Provincial Committee marked a new era because many believed that the 4.3

\footnotetext{
${ }^{48} 4.3$ Committee, Official Report of the National Committee for Investigation of the Truth About the Jeju 4.3 Events, 15.
} 
events and massacres were now officially no longer a taboo. A lesson could be learned that, if atrocities occurred at the local level, it is a good strategy to use the local government to strategically introduce interim transitional justice measures. The local government tends to be more attentive to the demands of activists and victims and it is much easier to move local politicians than national politicians and lawmakers. In addition, findings from local investigation can be further used as additional evidence and the local process provides realistic estimates of the national process.

Third, it was a victory of the indisputable evidence of the 4.3 events and massacres that tipped the scale in favor of activists and victims whenever there was a deadlock or confrontation. When the events are over fifty years old and previous regimes had been systematically destroying evidence and intimidating victims and witnesses to shut their mouths, it is extremely difficult to find evidence. Under these conditions, even the testimonies of victims and witnesses are ineffective since the general public has been constantly educated to accept the government's perspective and not to be deceived by "communist agitation." In other words, the Korean society itself had been built upon the grounds of forced oblivion and distorted understanding of the 4.3 events for fifty years. Thus, the role of evidence which is beyond dispute was an indispensable element to advance the movement. Concrete and indisputable evidence is the most effective way to defeat the endless objections and threats to the movement.

Two pieces of evidence were especially important - the Darangshi cave and the list of court-martialed persons. First, the Darangshi cave provided the 
momentum in creating the Provincial 4.3 Committee, which symbolized the transfer of accumulated societal activism into a public sector. The cave and the skeletal remains publicized and thereby made the public "see and believe" previous arguments and testimonies. Second, the list of court-martialed persons was a crucial motivator of the enactment process and effectively silenced objections. The timing of the release was extremely important in this case because the list made politicians act in the National Assembly. This shows that three elements of evidence are important: the content of the evidence, timing of the release, and the person or institution who releases the evidence. The release of the list was more effective because it was Choo who announced the list in a press conference and constantly asked for political action. The strategic calculation of the members of the 4.3 Research Institute to let Choo announce the document was successful in making the issue more attractive to the national media.

Finally, the role of culture was extremely important in bringing the hidden and suppressed issue of the 4.3 events. Cultural activism brought the forgotten discourses and lost memories back to life. The transitional justice movement was extremely difficult due to total suppression under the dictatorship of Rhee SyngMan and Park Chung-Hee. It was a courageous attempt of one writer Hyun KiYoung who first publicly mentioned the 4.3 events and massacres that first reopened the floodgate of transitional justice advocacy. Only after reading Aunt Suni, concerned individuals started to gather together and act together. New generations started to learn the 4.3 events and decided to devote themselves to 
finding the truth and restoring justice. Although Hyun did not intend or even know of this enormous impact, his short story had a huge repercussion and finally healed the depressed and shattered hearts of 15,000 victims and their family members. It was the relative distance of the cultural sector from governmental suppression and surveillance which provided the condition to make such a breakthrough possible. 


\section{Reference}

4.3 Committee. Official Report of the National Committee for Investigation of the Truth About the Jeju 4.3 Events. Seoul: 4.3 Committee, 2003.

4.3 Reporting Team. 4.3 Speaks. 5 vols. Vol. 4. Seoul: Jeonyeweon, 1997.

4.3 Research Institute, ed. A Study on the Jeju 4.3. Seoul: Yeoksa Bipyeong, 1999.

Backer, David. "Cross-National Comparative Analysis." In Assessing the Impact of Transitional Justice: Challenges for Empirical Research, edited by Audrey R. Chapman, Hugo Van der Merwe and Victoria Baxter. Washington: USIP Press, 2009.

Bongiorno, Carla. "A Culture of Impunity: Applying International Human Rights Law to the United Nations in East Timor." Columbia Human Rights Law Review 33, no. 3 (2001-2002): 623-92.

Brahm, Eric, Geoff Dancy, and Hunjoon Kim. "Truth Commission Database Project: What Is a Truth Commission and How Can We Understand It?" In International Studies Association Annual Meeting. San Francisco, CA, 2008.

Buergenthal, Thomas. "The United Nations Truth Commission for El Salvador." Vanderbilt Journal of Transnational Law 27, no. 3 (1994): 497 544.

Chapman, Audrey. R., and Patrick Ball. "The Truth of Truth Commissions: Comparative Lessons from Haiti, South Africa, and Guatemala." Human Rights Quarterly 23 (2001): 1 43.

Committee on Korean Police History. Korean Police History: Korean National Police, 1972.

Cumings, Bruce. "American Policy and Korean Liberation." In Without Parallel: The American Korean Relationship since 1945, edited by Frank Baldwin. New York: Pantheon Books, 1974.

_. "The Question of American Responsibility for the Suppression of the Chejudo Uprising." In 50th Anniversary Conference of the April 3rd, 1948 Chejudo Rebellion. Tokyo, 1988. 
Hayner, Priscilla B. Unspeakable Truth: Facing the Challenge of Truth Commission. New York: Routledge, 2002.

Huh, Ho-Joon. "A Study on the Process of the Jeju 4.3 and Counter-Strategy of the U.S. Military Government." Jeju National University, 2003.

Hyun, Ki-Young. Aunt Suni. Seoul: Changbi, 1979.

_. "The Motive of My Novel: 4.3 Uprising." Critical Review of Korean History, 20, no. Spring (1993): 163 70.

Jung, Hae-Gu. "Jeju 4.3 Uprising and the Policies of the U.S. Military

Government." In A Study on the Jeju 4.3, edited by 4.3 Research Institute, 180 204. Seoul: Yeoksa Bipyeong, 1999.

Jung, Seok-Kyun. "The Truth of Jeju 4.3 Events." Military 41 (2000): 1 49.

Kang, Duk-Hwan. "Overview of the 4.3 Movement." unpublished.

Kang, Sung-Hyun. "Sociological Study on the Jeju 4.3 Massacre." Seoul National University, 2002.

Kil, Seung-Heum. "The Birth and Development of Party Politics in Korea." In Modern Korean Politics 1945 1948, edited by Research Institute for Korean Politics. Seoul: Seoul National University, 1993.

Kim, Dong-Man. "The Darangshi Cave Should Be Recovered." Jeju Writers 8 (2002).

Kim, Jong-Min. "50 Years after 4.3." In Study of Jeju 4.3, edited by 4.3 Research Institute, 338 424. Seoul: Yeoksa Bipyeong, 1999.

Kim, Young-Bum, ed. A Struggle for Memory and the Development of Cultural Movement. Edited by 4.3 Research Institute. Seoul: Yeoksa Bipyeong, 2004.

Ko, Chang-Hoon. "The Process and Characteristic of the 4.3 Uprising." In Study of the Era of Korean Liberation, Vol. 4, edited by Chang Jip Choi, 245 340. Seoul: Hangilsa, 1989.

__. "A Story of Discovering the Darangshi Cave." unpublished.

_. "U.S. Government Responsibility in the Jeju April Third Uprising and Grand Massacre - Islanders' Perspective." Study of Regional Government 8, no. 2 (2004): 123 40. 
Lutz, Ellen, and Kathryn Sikkink. "The Justice Cascade: The Evolution and Impact of Foreign Human Rights Trials in Latin America." Chicago Journal of International Law 2, no. 1 (2001): 1 34.

Matheson, Michael J. "United Nations Governance of Post-Conflict Societies: East Timor and Kosovo." In Post-Conflict Justice, edited by M. Cherif Bassiouni, 523-36. Ardsley, NY: Transnational Publishers, 2002.

Oh, Bonnie B.C., ed. Korea under the American Military Government, 1945 1948. Westport, Conn.: Praeger, 2002.

Park, Chan-Sik. "A Massacre of Court-Martialed Persons Related to the 4.3 Events." 4.3 and History 1 (2001): 17 51.

Park, Myung-Lim. "A Study on the Jeju 4.3 Uprising." Korea University, 1988. Park, Won-Soon. "Bringing Justice to an Unjustified Past in Korea." Human Rights Dialogue 1, no. 8 (1997).

Provincial 4.3 Committee. "Report of the Jeju 4.3 Victims." edited by Jeju Provincial Council: Jeju Provincial Council, 1997.

Quinn, Joanna. R. "Constraints: The Un-Doing of the Uganda Truth Commission." Human Rights Quarterly 26 (2004): 401 27.

Quinn, Joanna. R., and Mark Freeman. "Lesson Learned: Practical Lessons Gleaned from inside the Truth Commissions of Guatemala and South Africa." Human Rights Quarterly 25 (2003): 1117 49.

Rotberg, Robert I, and Dennis Thompson, eds. Truth V. Justice: The Morality of Truth Commissions. Princeton: Princeton University Press, 2000.

Spiram, Chandra Lekha. "Dilemmas of Accountability: Politics, the Military and Commissions of Inquiry During an Ongoing Civil War - the Sri Lankan Case." Civil Wars 5, no. 2 (2002): 96 121.

The Office of the Secretariat of the Jeju Provincial Council. "A Minute of the 82nd Extraordinary Session (No.2)." 1993.

Tomuschat, Christian. "Clarification Commission in Guatemala." Human Rights Quarterly 23 (2001): 233-58.

Weissbrodt, David, and Paul W. Fraser. "Report of the Chilean National Commission on Truth and Reconciliation." Human Rights Quarterly 14, no. 4 (1992): 610 22. 
Yang, Han-Kwon. "A Study on the Jeju 4.3 Rebellion." Seoul National University, 1988.

Yang, Jung-Sim. "A Study on the Jeju 4.3 Uprising." Sungkyunkwan University, 1995.

Interviews

Kang, Duk-Hwan (A Secretary of the Office of 4.3 Victims Registration under the Provincial 4.3 Committee), Jeju, March 21, 2006.

Kim, Jong-Min (A Former Reporter of Jemin-Ilbo and the Staff of the Task Force for the Report under the 4.3 Commission), Seoul, March 25, 2006.

Kim, Kyung-Hoon (A Poet and Playwright and a Staff Member of the 4.3 Working Committee), Jeju, April 5, 2006.

Kim, Young-Hoon (A Former Chair of the Provincial 4.3 Committee), Jeju, April 7, 2006.

Ko, Chang-Hoon (A Professor in the Jeju National University and Former Director of the 4.3 Research Institute), Jeju, March 24, 2006.

Oh, Seung-Kook (A Secretary General of the 4.3 Research Institute and a Former President of the Jeju Cultural Movement Association), Jeju, April 7, 2006.

Park, Chan-Sik (A Director of the 4.3 Research Institute), Jeju, April 6, 2006.

Yang, Dong-Yoon (A Former Chairperson of the Provincial Solidarity), Jeju, March 22, 2006.

Yang, Jo-Hoon (A Chief Staff of the Task Force for the Report of the 4.3 Committee), Seoul, March 15, 2006. 